\title{
Free Will Skepticism in Law and Society: An Overview
}

Gregg D. Caruso, Elizabeth Shaw, and Derk Pereboom

Free will skepticism refers to a family of views that all take seriously the possibility that human beings lack the control in action - i.e., the free will - required for moral responsibility in a particular but pervasive sense. This sense is typically set apart by the notion of basic desert and is defined in terms of the control in action needed for an agent to be truly deserving of blame and praise, punishment and reward (see, e.g., Pereboom 200I, 20I4; Levy 20II; Caruso and Morris 20I7). For agents to be morally responsible for their actions in this sense is for the actions to be theirs in such a way that they would deserve to be blamed if they understood that it was morally wrong, and they would deserve to be praised if they understood that it was morally exemplary. The desert at issue here is basic in the sense that the agents would deserve to be blamed or praised just because they have performed the action, given an understanding of its moral status, and not, for example, by virtue of consequentialist or contractualist considerations (Pereboom 20I4: 2). Accordingly, here we will understand free will as the control in action required for basic desert moral responsibility, and free will skepticism as doubt or denial that we have this sort of control.

Some free will skeptics deny that we are morally responsible in this sense because they believe it is incoherent or impossible that we satisfy its control conditions (Strawson 1986, I994, 20II). That is, it's incoherent or impossible that we have the free will required to be morally responsible in this sense. Others maintain that, though not incoherent or impossible, our best philosophical and scientific theories about the word provide strong and compelling reasons for adopting the skeptical perspective. What all varieties of free will skepticism share, however, is the belief that the evidential standard for our having basic desert moral responsibility is not met, and as a result there is a strong presumption against the legitimacy of the practices associated with it - such as the reactive attitudes of resentment, indignation, backward-looking blame, and retributive punishment. 
Critics of free will skepticism argue that adopting such a view stands to have harmful consequences for our interpersonal relationships, society, morality, meaning, and the law. They contend, for instance, that relinquishing belief in free will and basic desert moral responsibility would undermine morality, leave us unable to adequately deal with criminal behavior, increase antisocial conduct, and destroy meaning in life. Optimistic free will skeptics respond by arguing that life without free will and basic desert moral responsibility would not be harmful in these ways, and may even be beneficial. Prospects of finding meaning in life or of sustaining good interpersonal relationships, for instance, would not be threatened. They further maintain that morality and moral judgments would remain intact. And although retributivism and severe punishment, such as the death penalty, would be ruled out, imposition of sanctions could serve purposes other than the punishment of the guilty; e.g., it can be justified by its role in incapacitation, rehabilitation, and deterring offenders.

In this introduction we attempt to provide a brief sketch of the traditional free will debate, define the various positions, and frame the debate over the practical implications of free will skepticism. We focus especially on the implications of free will skepticism for the criminal law and the retributive justification of punishment. We conclude with a summary of the ten original chapters to follow.

\section{I.I Free Will Skepticism and Its Implications}

Contemporary theories of free will might be divided into two general categories: those that endorse and those that are skeptical of the claim that human beings have free will. ${ }^{\mathrm{I}}$ The former category includes libertarian and compatibilist accounts of free will, two general views that defend the claim that we have free will but disagree on its nature or its conditions. The second category comprises a family of skeptical views that doubt or deny human free will. The main dividing line between the two pro-free will positions, libertarianism and compatibilism, is best understood in terms of the traditional problem of free will and determinism. Determinism, as it is commonly understood, is the thesis that every event or action, including human action, is the inevitable result of antecedent circumstances in accordance with the laws of nature. The traditional problem of free will and determinism therefore comes in trying to reconcile our intuitive sense

I This section includes some passages from Caruso (2013). 
of free will with the idea that our choices and actions may be causally determined by factors over which we have no ultimate control; that is, the past before we were born and the laws of nature.

Libertarians and compatibilists react to this problem in different ways. Libertarians acknowledge that, if determinism is true, and all of our actions were causally determined by antecedent circumstances, we would lack free will and moral responsibility. Yet they further maintain that at least some of our choices and actions must be free in the sense that they are not causally determined. Libertarians therefore reject determinism and defend an indeterminist conception of free will in order to save what they maintain are necessary conditions for free will - the ability to do otherwise in exactly the same set of conditions and/or the idea that we remain, in some important sense, the ultimate source/originator of action. Compatibilists, on the other hand, set out to defend a conception of free will that can be reconciled with determinism. They hold that what is of utmost importance is not the absence of causal determination, but that our actions are voluntary, free from constraint and compulsion, and caused in the appropriate way. Different compatibilist accounts spell out requirements for free will differently but widely endorsed views single out responsiveness to reasons or connection of action to what one would reflectively endorse.

Free will skepticism stands in contrast to these pro-free will positions, and the skeptical view is the focus of this collection. In the past, the leading form of skepticism was hard determinism: the view that determinism is true, and determinism is incompatible with free will either because it precludes the ability to do otherwise (leeway incompatibilism) or because it is inconsistent with one's being the ultimate source of action (source incompatibilism) - hence, no free will. For hard determinists, libertarian free will is an impossibility because human actions are part of a fully deterministic world and compatibilism is operating in bad faith.

Hard determinism had its classic statement in the time when Newtonian physics reigned supreme and was thought to be deterministic. The development of quantum mechanics diminished confidence in determinism, for the reason that it has indeterministic interpretations. This is not to say that determinism has been refuted or falsified by modern physics, because a number of leading interpretations of quantum mechanics are consistent with determinism (Lewis 20I6). It is also important to keep in mind that even if we allow some indeterminacy to exist at the microlevel - the level studied by quantum mechanics - there would still likely remain determinism where it matters. As Ted Honderich argues: "At the 
ordinary level of choices and actions, and even ordinary electrochemical activity in our brains, causal laws govern what happens. It's all cause and effect in what you might call real life" (Honderich 2002: 5; see also Honderich 1988). ${ }^{2}$ Nonetheless, most contemporary skeptics tend to defend positions that are best seen as distinct from, but successors to, traditional hard determinism.

In recent years, for instance, several philosophers have defended free will skepticism on grounds that are agnostic about determinism; e.g., Galen Strawson (1986), Richard Double (199I), Saul Smilansky (2000), Derk Pereboom (200I, 20I4), Neil Levy (20II), Bruce Waller (20II), and Gregg Caruso (2012). ${ }^{3}$ Most maintain that, while determinism is incompatible with free will and moral responsibility, so too is indeterminism, especially if it is limited to the sort posited by certain interpretations of quantum mechanics (Pereboom 200I, 20I4; Caruso 2012). Others argue that, regardless of the causal structure of the universe, we lack free will and moral responsibility because free will is incompatible with the pervasiveness of luck (Levy 20I i; Caruso 2019a). Others argue that free will and ultimate moral responsibility are incoherent concepts, since to be free in the sense required for ultimate moral responsibly we would have to be causa sui (or cause of oneself) and this is impossible (Strawson 1994, 20 I I). Here, for example, is Nietzsche on the causa sui:

${ }^{2}$ Cf. Balaguer (2009). But even if some brain processes are indeterministic, it isn't clear how that would give us free will. Although free will arguably requires indeterminacy, it also requires significant control in action, and Balaguer's view has been criticized for its inability to supply that control (see, e.g., Pereboom 2014).

3 We've included Bruce Waller and Saul Smilansky on this list but it's important to note how their views differ from most other skeptics. Waller is a moral responsibility skeptic who wishes to "destroy moral responsibility, drive a stake in its heart, and bury it at the crossroads" (Waller 201 5: viii), yet he also defends a restorative account of free will that is naturalistic, nonmiraculous, and freed from the burden of trying to justify moral responsibility (see Waller 20I 5). This view differs from the majority of skeptics who define free will in terms of basic desert moral responsibility and maintain that the two must stand or fall together (see, e.g., Pereboom 200I, 20I4; Levy 20 I I; Caruso 20I 2; Strawson I986, I994; Morris 20I5; Shaw 20II, ch.II; Focquaert 2019, ch.I2; Caruso and Morris 2017; Focquaert, Glenn, and Raine 2018). Saul Smilansky's (2000) fundamental dualism, on the other hand, maintains a skepticism about our purportedly commonplace belief in libertarian free will but he also maintains that compatibilism retains some truth. As Smilansky describes: "I agree with hard determinists that the absence of libertarian free will is a grave matter, which ought radically to change our understanding of ourselves, of morality, and of justice. But I also agree with the compatibilists that it makes sense to speak about ideas such as moral responsibility and desert, even without libertarian free will (and without recourse to a reductionist transformation of these notions along consequentialist lines). In a nutshell, ... 'forms of life' based on the compatibilist distinctions about control are possible and morally required, but are also superficial and deeply problematic in ethical and personal terms" (Smilansky 2000: 5; see also Chapter 2 [this volume]). 
The causa sui is the best self-contradiction that has been conceived so far; it is a sort of rape and perversion of logic. But the extravagant pride of man has managed to entangle itself profoundly and frightfully with just this nonsense. The desire for "freedom of the will" in the superlative metaphysical sense, which still holds sway, unfortunately, in the minds of the half-educated; the desire to bear the entire and ultimate responsibility for one's actions oneself, and to absolve God, the world, ancestors, chance, and society involves nothing less than to be precisely this causa sui and, with more than Baron Munchhausen's audacity, to pull oneself up into existence by the hair, out of the swamps of nothingness. (Nietzsche 1886/1992: 218-219)

What all these skeptical arguments have in common, and what they share with classical hard determinism, is the belief that what we do and the way we are is ultimately the result of factors beyond our control, and because of this we are not morally responsible for our actions in the basic desert sense. This is not to say that there are no other conceptions of moral responsibility that can be reconciled with determinism, chance, or luck (see, e.g., Pereboom 2014; Caruso 2018a). Nor is it to deny that there may be good pragmatic reasons to maintain certain systems of punishment and reward. Rather, it is to contend that to hold people morally responsible for their actions in the basic desert sense is fundamentally unfair and unjust because we lack the control in action that this requires.

In addition to these philosophical arguments, there have also been recent developments in the behavioral, cognitive, and neurosciences that have caused some to take free will skepticism seriously - though there is much controversy regarding these scientific arguments (see Mele 2009; Nahmias 2002, 20II; Levy 2005; Pereboom and Caruso 2018). Chief among these developments have been findings in neuroscience that appear to indicate that unconscious brain activity causally initiates action prior to the conscious awareness of the intention to act and recent findings in psychology and social psychology on automaticity, situationism, and the adaptive unconscious. ${ }^{4}$ Viewed collectively, these developments appear to indicate that much of what we do takes place at an automatic and unaware level and that our commonsense belief that we consciously initiate and control action may be mistaken. They also indicate that the causes that

\footnotetext{
4 See, for example, Libet et al. (1983); Libet (1985, 1999); Soon et al. (2008); Wegner (2002); Wegner and Wheatley (1999); Bargh (1997, 2008); Bargh and Chartrand (1999); Bargh and Ferguson (2000); Wilson (2002); Nisbett and Wilson (1977); Doris (2002). The literature on Social Intuitionism (e.g., Haidt 200I) is also sometimes cited in this regard; see Sie (2013) for a brief discussion of its possible relevance.
} 
move us are often less transparent to ourselves than we might assume diverging in many cases from the conscious reasons we provide to explain and/or justify our actions. These findings reveal that the higher mental processes that have traditionally served as quintessential examples of free will - such as goal pursuits, evaluation and judgment, reasoning and problem solving, interpersonal behavior, and action initiation and control can and often do occur in the absence of conscious choice or guidance (Bargh and Ferguson 2000: 926). They also reveal just how wide open our internal psychological processes are to the influence of external stimuli and events in our immediate environment, without knowledge or awareness of such influence. For many, these findings represent a serious threat to our everyday folk understanding of ourselves as conscious, rational, responsible agents, since they indicate that the conscious mind exercises less control over our behavior than we have traditionally assumed.

Even some compatibilists agree that, because of these behavioral, cognitive, and neuroscientific findings, "free will is at best an occasional phenomenon" (Baumeister 2008: 17). This is an important concession because it acknowledges that the threat of shrinking agency, as Thomas Nadelhoffer (20 I I) calls it, is a serious one independent of any traditional concerns over determinism. That is, even if one believes free will and causal determinism can be reconciled, the deflationary view of consciousness that emerges from these empirical findings must still be confronted, including the fact that we often lack transparent awareness of our true motivational states. Such a deflationary view of consciousness is potentially agency undermining (see, e.g., Davies 2009; Sie and Wouters 2010; Nadelhoffer 20II; Caruso 20I2, 20I5, 20I8d; King and Carruthers 20I2; Levy 20I4) and must be dealt with independent of, and in addition to, the traditional compatibilist/incompatibilist debate.

In addition to these specific concerns over conscious volition and the threat of shrinking agency, there is also the more general insight, more threatening to agent-causal libertarianism than compatibilism, that, as the brain sciences progress and we better understand the mechanisms that undergird human behavior, the more it becomes obvious that we lack what Tom Clark (2013) calls "soul control." There is no longer any reason to believe in a nonphysical self that controls action and is liberated from the deterministic laws of nature; a little uncaused causer capable of exercising countercausal free will. While most naturalistically inclined philosophers, including most compatibilists, have long given up on the idea of soul control, eliminating such thinking from our folk psychological attitudes may not be so easy and may come at a cost for some. There is some 
evidence, for example, that we are "natural-born" dualists (Bloom 2004) and that, at least in the United States, a majority of adults continue to believe in a nonphysical soul that governs behavior (Nadelhoffer 20 I4). To whatever extent, then, such dualistic thinking is present in our folk psychological attitudes about free will and moral responsibility, it is likely to come under pressure and require some revision as the brain sciences advance and this information reaches the general public. ${ }^{5}$

What, then, would be the consequence of accepting free will skepticism? What if we came to disbelieve in free will and basic desert moral responsibility? What would this mean for our interpersonal relationships, society, morality, meaning, and the law? What would it do to our standing as human beings? Would it cause nihilism and despair as some maintain? Or perhaps increase antisocial behavior as some recent studies have suggested (Vohs and Schooler 2008; Baumeister, Masicampo, and DeWall 2009; cf. Caruso, Chapter 3 in this volume)? Or would it rather have a humanizing effect on our practices and policies, freeing us from the negative effects of free will belief? These questions are of profound pragmatic importance and are of interest independent of the metaphysical debate over free will. As public proclamations of skepticism continue to rise, and as the mass media continue to run headlines announcing: "Free will is an illusion" and "Scientists say free will probably doesn't exist," we need to ask what effects this will have on the general public and what the responsibility is of professionals.

In recent years a small industry has actually grown up around precisely these questions. In the skeptical community a number of different positions have been developed and advanced, including Saul Smilansky's illusionism (2000), Thomas Nadelhoffer's disillusionism (201 I), and the optimistic skepticism of Derk Pereboom (200I, 20I3a,b, 20I4), Bruce Waller (20II), and Gregg D. Caruso (2016, 2017, 20I8b; Pereboom and Caruso 2018).

Saul Smilansky, for example, maintains that our commonplace beliefs in libertarian free will and desert entailing ultimate moral responsibility are illusions, but he also maintains that if people were to accept this truth there would be wide-reaching negative intrapersonal and interpersonal consequences. According to Smilansky, "Most people not only believe in actual

\footnotetext{
s Predicting what revisions will be made is difficult. It's possible that relinquishing the folk psychological idea of "soul control" will cause some to accept free will skepticism. But it's also possible that some might adopt a free-will-either-way strategy, causing them to accept compatibilism on pragmatic grounds, fearing the alternative.

6 The Chronicle Review (March 23, 2012) and Scientific American (April 6, 2010) respectively.
} 
possibilities and the ability to transcend circumstances, but have distinct and strong beliefs that libertarian free will is a condition for moral responsibility, which is in turn a condition for just reward and punishment" (Smilansky 2000: 26-27). It would be devastating, he warns, if we were to destroy such beliefs: "[T]he difficulties caused by the absence of ultimate-level grounding are likely to be great, generating acute psychological discomfort for many people and threatening morality-if, that is, we do not have illusion at our disposal" (Smilansky 2000: I66). To avoid any deleterious social and personal consequences, then, and to prevent the unraveling of our moral fabric, Smilansky recommends free will illusionism. According to illusionism, people should be allowed their positive illusion of libertarian free will and with it ultimate moral responsibility; we should not take these away from people, and those of us who have already been disenchanted ought to simply keep the truth to ourselves.

In direct contrast to Smilansky's illusionism, Thomas Nadelhoffer defends free will disillusionism: "[T]he view that to the extent that folk intuitions and beliefs about the nature of human cognition and moral responsibility are mistaken, philosophers and psychologists ought to do their part to educate the public - especially when their mistaken beliefs arguably fuel a number of unhealthy emotions and attitudes such as revenge, hatred, intolerance, lack of empathy, etc." (Nadelhoffer 20 I : I84). According to Nadelhoffer, "humanity must get beyond this maladaptive suit of emotions if we are to survive." And he adds, "To the extent that future developments in the sciences of the mind can bring us one step closer to that goal-by giving us a newfound appreciation for the limits of human cognition and agency-I welcome them with open arms" (Nadelhoffer 20I I: I84).

A policy of disillusionism is also present in the optimistic skepticisms of Derk Pereboom, Bruce Waller, and Gregg Caruso. Derk Pereboom, for example, has defended the view that morality, meaning, and value remain intact even if we are not morally responsible in the basic desert sense, and furthermore, that adopting this perspective could provide significant benefits for our lives. In Living Without Free Will (200I) and again in Free Will, Agency, and Meaning in Life (2014), Pereboom argues that life without free will and basic desert moral responsibility would not be as destructive as many people believe. Prospects of finding meaning in life or of sustaining good interpersonal relationships, for example, would not be threatened. And although retributivism and severe punishment, such as the death penalty, would be ruled out, preventive detention and rehabilitation programs would be justified (Pereboom 200I, 20I3a, 20I4). He also 
contends that relinquishing our belief in free will might well improve our well-being and our relationships to others since it would tend to eradicate an often destructive form of moral anger.

Bruce Waller has also made a strong case for the benefits of a world without moral responsibility (see Waller 20II, 20I3, 20I4a, b. He cites, for example, many instances in which moral responsibility practices are counterproductive from a practical and humanitarian standpoint - notably in how they stifle personal development, encourage punitive excess in criminal justice, and perpetuate social and economic inequalities. Waller suggests that, if we abandon moral responsibility, "we can look more clearly at the causes and more deeply into the systems that shape individuals and their behavior" (Waller 20 I I: 287), and this will allow us to adopt more humane and effective interpersonal attitudes and approaches to education, criminal justice, and social policy. He maintains that, in the absence of moral responsibility, "it is possible to look more deeply at the influences of social systems and situations" (Waller 20I I: 286), to minimize the patent unfairness that luck deals out in life, and to "move beyond [the harmful effects of] blame and shame" (Waller 20II: 287).

Who, then, is correct? What would the consequences of embracing free will skepticism be for society? And what about the criminal law? Would it need to be abandoned or drastically revised? These are just some of the questions this collection promises to explore.

\section{I.2 Free Will and the Criminal Law}

One impact the free will debate has already had on criminal law theory is in relation to the causal theory of excuses. "Excuse" in this context is used in a broad sense to refer to situations where an agent is considered not to be blameworthy even though the behavior was prohibited and was not justified. In the literature on causal theory the term excuse is used to cover certain defenses that some writers do not regard as true excuses, including defenses that involve denying that the accused had mens rea or that her behavior constituted an action, or that the accused possessed the general capacities necessary to qualify as a moral agent (e.g., Moore I985). According to causal theory, the criminal law presumes that agents generally have libertarian free will. ${ }^{7}$ But the law recognizes that, on some occasions,

\footnotetext{
7 The following writers endorse this view. On English law, see Ashworth stating that "there are a few defences in which elements of determinism play a significant role (involuntariness, duress, perhaps insanity)" (Ashworth I994: 8). On North American law, see e.g., Kaye (2005) and Morris (I982).
} 
factors outside the agents' control are either causally sufficient to produce the agents' behavior or exert such a heavy causal influence on their conduct that they are not blameworthy for that conduct. Examples often cited by the causal theorist include reflex actions and coercion. On such occasions, the causal theory contends that the law should not hold the agent criminally responsible and the accused does not deserve punishment.

The opponents of causal theory - compatibilists about criminal law vary in their positive accounts of criminal responsibility and excuse, but they all agree that causal determinism has nothing to do with liability to retributive punishment (see, e.g., Moore 1985; Vuoso 1987; Pillsbury 1992; Morse 1994; Horder 1996; Litton 2005). "Choice" theorists, for instance, argue that people are responsible for their choices even if those choices were the inevitable product of factors beyond their control (Moore 1997). Behavior is excused if it is not the result of an agent's choice, or if the agent was not sane, or not mature enough to be blamed for the choice; or if the agent made the choice for acceptable reasons, e.g. to avoid a "substantial evil." "Character" theorists claim that people are only responsible for actions that reflect their (predetermined) characters. On one version of this theory, actions do not reflect the agents' character if they spring from a desire that the agents do not accept in the light of their value systems (Tadros 2005). According to some character theorists, agents may be excused if their actions do reflect their characters, but do not show their characters to have unacceptable flaws (Horder 2004). "Attitude" theorists claim that people are punished for actions that reflect certain attitudes of hostility or disrespect, regardless of whether the persons were predetermined by factors outside their control to have those attitudes. On this theory, people may be excused if their conduct does not in fact express an unacceptable attitude (because, for instance, it was involuntary) or if they are not the kind of agents from whom the criminal law demands an attitude of respect, e.g. an individual incapable of practical reasoning (Western 2006; see also Strawson 1962).

\footnotetext{
On Scots law, see Gordon stating that, "Voluntary human actions are ... regarded as themselves uncaused. This is a necessary inference from the doctrine of freewill; and without some form of that doctrine, however restricted, there can be no moral responsibility in the sense of praise or blame" (Gordon I984: II 8-II9). He cites coerced and reflex "acts" as instances where behavior is regarded as a mere effect of prior causes and where the actor is not held legally responsible. However, in an earlier passage he argues that practices of praise, blame, reward, and punishment can still be justified even if determinism is true, since such practices can still be an effective means of improving behavior (Gordon I984: 5I-53). Perhaps the best way of reconciling the two passages is to interpret Gordon as arguing that without free will there can be no moral responsibility in the sense of praise and blame without pragmatic justification. On Australian law, see Hodgson (2009).
} 
While free will is relevant to the causal theory since, for instance, it maintains that the culpability of agents is mitigated by circumstances that constrain free will, the relevance of the free will debate to the criminal law goes much deeper than this. This is because the criminal law is founded on the idea that most normal, rational persons can be held morally responsible for their actions since they have freely chosen them - if this is mistaken, the entire foundation of the criminal law is defective. The US Supreme Court, for instance, has asserted:

A "universal and persistent" foundation stone in our system of law, and particularly in our approach to punishment, sentencing, and incarceration, is the "belief in freedom of the human will and a consequent ability and duty of the normal individual to choose between good and evil." ${ }^{18}$

Indeed, US courts have observed that, "[t] he whole presupposition of the criminal law is that most people, most of the time, have free will within broad limits." Moreover, "the law has been guided by a robust common sense which assumes the freedom of the will as a working hypothesis in the solution of its problems." ${ }^{10}$ The US Supreme Court, in fact, has gone so far as to suggest that "a deterministic view of human conduct ... is inconsistent with the underlying precepts of our criminal justice system." ${ }^{\text {I }}$ While this last claim is controversial, since some legal scholars claim that the criminal law only requires compatibilist free will, one thing is clear: if free will skepticism is correct and agents are never morally responsible in the basic desert sense, the current American conception of the criminal law will need to be revised.

Legal punishment consists in the state deliberately harming an individual in a way that is intended to constitute a fitting response to some offense and to give expression to the state's disapproval of that offense (Boonin 2008; Zimmerman 20II). One prominent justification for legal punishment is retributivism. The retributivist justification for punishment maintains that punishment of wrongdoers is justified for the reason that they deserve pain, deprivation, or death just because they have knowingly done wrong; it is the basic desert attached to criminals' immoral actions alone

8 United States v. Grayson, 438 U.S. 4I at 52 (1978), quoting Morissette v. United States, 342 U.S. 246, 250 (1952).

9 Smith v. Amontrout, 865 F.2d I 502, I 506 (8th Cir. 1988).

ro Steward Machine Co. v. Davis, 30 I U.S. 548.590 (1937).

${ }^{I I}$ United States v. Grayson, 438 U.S. 4I at 52 (1978). See also Bethea v. United States, 365 A.2d 64, 83 n.39 (D.C. 1976), which asserts: "the notion that a person's conduct is a simple function of extrinsic forces and circumstances over which he has no control is an unacceptable contradiction of the concept of free will, which is the sin qua non of our criminal justice system." 
that provides the justification for harming them in such ways. This means that the retributivist justification for punishment does not appeal to goods such as the safety of society or the moral improvement of those being punished.

In the United States, a number of sentencing guidelines have adopted desert as their distributive principle, ${ }^{\mathrm{I} 2}$ and it is increasingly given deference in the Purposes section of state criminal codes, ${ }^{13}$ where it can be the guiding principle in the interpretation and application of the code's provisions. ${ }^{\mathrm{I}}$ Indeed, the American Law Institute recently revised the Model Penal Code so as to set desert as the official dominate principle for sentencing. ${ }^{15}$ And courts have identified desert as the guiding principle in a variety of contexts, ${ }^{16}$ as with the Supreme Court's enthroning retributivism as the "primary justification for the death penalty" ${ }^{\text {"7 }}$ (Robinson 2008: I45-I46).

Legislation in England and Wales ${ }^{18}$ and draft sentencing guidelines in Scotland also list punishment as the first aim in a list of the purposes of criminal sentencing. Since the other purposes that appear in the list are forward-looking goals that punishment might seek to achieve (e.g. crime reduction), commentators have observed that singling out punishment as a separate aim of sentencing seems to appeal to the retributive idea that punishment can be an end in itself. ${ }^{19}$ It has also been suggested that placing punishment first in the list implies that it is the most important aim, even though the legislation and draft guidelines do not explicitly say that. ${ }^{20}$

Consider, for instance, the American Law Institute's recent revision of the Purposes section of the Model Penal Code. The Model Penal Code is one of the most important developments in American law, and perhaps the

${ }^{12}$ E.g., 204 Pa. Code Sect. 303.I I (2005); see also (Tonry 2004).

${ }^{13}$ E.g., Cal. Penal Code Sect. I I70(a)(I) (West I985): "The legislature finds and declares that the purpose of imprisonment for crime is punishment."

${ }^{1}$ E.g., Model Penal Code Sect. I.02(2) (Official Draft I962).

I5 American Law Institute, Model Penal Code Sect. I.02(2) adopted May 24, 2017.

${ }^{16}$ See, for example, the US cases Spaziano v. Florida, 468 U.S. 447, 462 (1984); Gregg v. Georgia, 428 U.S. I 53, I83-84 (1976); Cotton (2000).

17 Spaziano v. Florida, 468 U.S. at 46I.

${ }_{18}$ Criminal Justice Act 2003, si42, I(a); Scottish Sentencing Council (2017), Principles and Purposes of Sentencing. Draft Sentencing Guidelines, 2(i): www.scottishsentencingcouncil.org .uk/consultations/principles-and-purposes-of-sentencing/.

I9 Dingwall (2008).

${ }^{20}$ Dingwall (2008); see also Scottish Sentencing Council (2018: I 5), Principles and Purposes of Sentencing, Consultation Analysis: www.scottishsentencingcouncil.org.uk/consultations/ principles-and-purposes-of-sentencing/. 
most important influence on American criminal law. Conceived as a way to standardize and organize the often-fragmentary criminal codes enacted by the states, the Model Penal Code has influenced a large majority of states to change their laws. While the Model Penal Code is not law and has no binding effect, it has been the model for many states' criminal codes and has been extremely influential on state and local lawmakers.

The new Purposes provision of the Model Penal Code (revised in May 20I7) now states:

\section{$\$$ I.02(2). Purposes; Principles of Construction}

(2) The general purposes of the provisions on sentencing, applicable to all official actors in the sentencing system, are:

(a) in decisions affecting the sentencing of individual offenders:

(i) to render sentences in all cases within a range of severity proportionate to the gravity of offenses, the harms done to crime victims, and the blameworthiness of offenders;

(ii) when reasonably feasible, to achieve offender rehabilitation, general deterrence, incapacitation of dangerous offenders, restoration of crime victims, preservation of families, and reintegration of offenders into the law-abiding community, provided these goals are pursued within the boundaries of proportionality in subsection (a) (i);

(iii) to render sentences no more severe than necessary to achieve the applicable purposes in subsections (a)(i) and (a)(ii) ...

It is the inclusion of (2)(a)(i) that colors the entire Model Penal Code and sets retributivism as the official dominant principle for sentencing. While (2)(a)(ii) and (2)(a)(iii) are not retributive in nature, they are secondary to the subsection setting the "blameworthiness of offenders" as the primary justification for criminal sentencing. Note, first, that retributivism is to guide sentencing "in all cases," while rehabilitation, deterrence, incapacitation, and restorative justice are only to be pursued "when reasonably feasible." Second, the provision clearly states that (2)(a)(i) trumps (2)(a)(ii) in that the forward-looking, nonretributive approaches cited in (a)(ii) are only to be pursued "within the boundaries of proportionality in subsection (a)(i)." This amounts to saying that limits to punishment grounded in retributivism cannot legitimately be overridden for forward-looking reasons.

The revised Purposes section rests upon the theory of limited retributivism, setting a maximum and minimum for all sentencing based upon deontological and retributive principles, and allowing for forwardlooking, nonretributive options only "when reasonably feasible" and 
"within the boundaries of proportionality." This conflicts with skepticism about free will for at least two reasons. First, if free will skeptics are correct, retributive legal punishment is unjustified since, if agents do not deserve blame just because they have knowingly done wrong, neither do they deserve punishment just because they have knowingly done wrong (Pereboom 20 I4: I 57). This would remain true whether or not the criminal law assumes libertarian free will, since free will skepticism also denies that compatibilism preserves the kind of free will and moral responsibility needed to justify retributive legal punishment. Thus, upper and lower bounds on punishment cannot be grounded in retributivist theory.

Commenting on the significance of what free will and moral responsibility skepticism entails, Neil Levy writes:

Traditionally, incarceration is seen as justified, in part, by the desert of offenders: because they are guilty—morally, and not merely legally, guiltywe can impose significant sanctions on them; the more weighty the sanctions, the more such a justification is required. . But if moral responsibility skeptics are right, agents are never deserving of the imposition of such sanctions. Thus moral responsibility skepticism has practical implications: it apparently entails that major elements of the criminal justice system are unjustified. (Levy 20I 2: 48I)

By setting desert as the official dominant principle for sentencing, the Model Penal Code, as well as numerous sentencing guidelines in the United States, England, Scotland, and elsewhere, has assumed that "most people, most of the time, have free will within broad limits." If the proponents of free will skepticism are correct, this assumption is mistaken.

Furthermore, even if one is not convinced by the arguments for free will skepticism, it remains unclear whether punishment can be justified on retributive grounds. This is because the burden of proof lies on those who want to inflict harm on others to provide good justification for such harm (Pereboom 200I, 20I4; Shaw 20I4; Corrado 2017; Caruso 20I8c). This means that retributivists who want to justify legal punishment on the assumption that agents are free and morally responsible (and hence justly deserve to suffer for the wrongs they have done) must justify that assumption. And they must justify that assumption in a way that meets a high epistemic standard of proof since the harms caused in the case of legal punishment are often quite severe. It is not enough to simply point to the mere possibility that agents possess libertarian or compatibilist free will. Nor is it enough to say that the skeptical arguments against free will and basic desert moral responsibility fail to be conclusive. Rather, a positive and convincing case must be made that agents are in fact morally 
responsible in the basic desert sense, since it is the backward-looking desert of agents that retributivists take to justify the harm caused by legal punishment.

If we accept, then, that we are justified in doubting or denying the existence of free will and basic desert moral responsibility, as skeptics contend, a major challenge remains: providing an ethically defensible and practically workable alternative to retributive legal punishment. It is exactly this challenge that several of the contributions to this volume attempt to tackle.

\section{I.3 Overview of Chapters}

The collection is divided into three main parts. Part I is concerned with the possibility and desirability of rejecting the notions of free will, basic desert moral responsibility, and retribution. Part II takes up the challenge just mentioned and asks: how can the use of state coercion be justified without retributivism? Part III discusses some of the needed changes to the criminal justice system if we adopted free will skepticism.

Part I begins with Saul Smilansky's (Chapter 2) critique of the skeptics' claim that relinquishing basic desert does not expose us to abuse of the sort referenced in traditional objections to utilitarianism, such as that it will justify punishment of the innocent. Smilansky offers seven reasons for doubting this claim - some philosophical, others more pragmatic. One of his central contentions is that free will skepticism (or free will denialism, as he prefers to call it) does not have the philosophical resources to effectively safeguard human rights and respect for persons in the context of punishment. We should be skeptical of the optimism of free will denialists concerning the stability of deontological constraints without free will and moral responsibility. Smilansky concludes that these considerations should lead us to adopt his fundamental dualism and illusionism.

Contra Smilansky, Gregg D. Caruso argues in Chapter 3 that we should instead be optimistic about the implications of free will skepticism. He considers the practical implications of free will skepticism and discusses recent empirical work that has just begun to investigate the matter. $\mathrm{He}$ argues that there are good philosophical and empirical reasons for thinking that belief in free will, rather than providing the pragmatic benefits many claim, actually has a dark side; i.e., it is too often used to justify punitive excess in criminal justice, to encourage treating people in severe and demeaning ways, and to excuse and perpetuate social and economic inequalities. The problem, he contends, is the belief in just deserts. After 
addressing recent empirical findings in social psychology that purport to show that diminishing one's belief in free will increases antisocial behavior - findings he argues are overblown and questionable - he introduces contrary findings in moral and political psychology that reveal interesting and troubling correlations between people's free will beliefs and their other moral, religious, and political beliefs. He concludes that we would be better off without the notions of free will and just deserts.

In Chapter 4, Bruce Waller argues that the desire for retribution runs deep - its roots are in the same strike-back desire that motivates rats to attack each other when they are placed in a cage with an electrified grid and then shocked. Rats, however, "didn't have anyone around to justify their strike-back behavior by constructing a system of moral responsibility and righteous retribution; unfortunately, humans do." Waller notes that the primitive strike-back desire is philosophically packaged as righteous retribution, the essential basis of morality, justice, and human dignity, but this is because we are stuck within the retributive thought system. We need to move beyond the retributive system to something that works. And while we may need the strike-back retributive emotions, we also need ways of controlling and ultimately reducing them. When the strike-back feelings linger and fester, they not only block better ways of dealing with the problem of criminal behavior, they also exact an additional psychological toll on the crime victim. After examining some of the psychological and cultural factors that hold the retributive system in place - e.g., belief in a just world, belief in rugged individualism and self-making, and belief in moral responsibility - Waller argues that we need to drop the moral responsibility system altogether and move "beyond blame and shame." The path beyond retributivism leads to the search for greater understanding of individual behavior and its causes. He concludes by examining what direction the criminal justice system might take in a world without moral responsibility.

Part II of the collection begins with Derk Pereboom's chapter on free will skepticism and criminal behavior. In it, he sets out the most recent version of his free will skeptical position on treatment of criminals, which combines detention for dangerous criminals by analogy with quarantine for carriers of dangerous diseases, justified on the basis of the self-defense right, the attendant special deterrent effect, and restricted general deterrence (Pereboom 200I, 20I4, 20I8). Saul Smilansky contends that Pereboom relinquishes a traditional safeguard against unjust treatment, the principle that only the guilty should be punished because only they basically deserve to be punished. Pereboom agrees that the safeguards his 
view provides are sufficiently robust, and are workable in societies generally committed to the well-being of its citizens. These safeguards include the fact that the right to self-defense, on which his quarantine analogy is founded, is not dependent on basic desert, while it permits harming in self-defense only those who are evidently an immediate threat. A further safeguard, the right to liberty, is also not dependent on basic desert. In addition, there is significant value to basing criminal law in views about human beings that can be defended, by contrast with concealing, for the sake of the public good, what one, after serious rational consideration, believes to be the truth.

In Chapter 6, Benjamin Vilhauer develops a deontological social contract approach to punishment that draws on Kantian and Rawlsian notions of treating criminals as ends by respecting their rational consent to punishment. In developing his account, he responds to Saul Smilansky's objection that free will deniers do not have the philosophical resources to effectively safeguard human rights and respect for persons in the context of punishment. Vilhauer agrees that utilitarian approaches to punishment are problematic for the reasons Smilansky states, but he disagrees with Smilansky that free will deniers are unable to offer a deontological justification for punishment that respects persons. Vilhauer's deontological account draws on a broadly Rawlsian version of the Kantian idea of refraining from treating people as mere means to ends. He argues that a Rawlsian social contract theory that models rational consent is perfectly consistent with free will skepticism and is able to safeguard human rights and respect for persons - and this is because there is an important moral distinction between the action-based kind of desert typically at issue in the free will literature (which is inconsistent with free will skepticism) and personhoodbased desert (which is not). He concludes that free will deniers can justify punishment despite establishing deontological rights against the unfairness involved in maximally painful punishment, violations of due process, and framing.

In Chapter 7, Kevin Murtagh defends the view that free will skeptics can endorse general deterrence as a justifiable aim of legal punishment. $\mathrm{He}$ does not claim that it is the justifiable aim, or the main aim, but rather that it is a justifiable aim among others. He takes as his target Derk Pereboom's claim that general deterrence is not a justifiable aim of punishment since it suffers from the "use" objection, according to which general deterrence is wrong because it involves harming some, without their consent, in order to benefit others. Murtagh responds by arguing that the use objection myopically focuses on only one aspect of a system of general deterrent 
punishment, and that, when we take full account of the complexity of this sort of punishment within a reasonably just legal system, we can see that it need not involve an impermissible kind of use. He further argues that Pereboom's positive account of how to respond to crime is insufficient for good social policy. He concludes by offering a sketch of an account that combines the measures that Pereboom advocates with others designed to promote general deterrence.

Part III of the book, which focuses on changes to the criminal justice system, begins in with Michael L. Corrado's chapter (Chapter 8) on "criminal justice turned upside down." He begins by noting that those who reject the notion of moral responsibility seem to fall into one or the other of two camps: those who prefer to abandon punishment in favor of preventive techniques - therapy and incapacitation - and those who seek to justify (nonretributive) punishment nevertheless. Corrado places his tent on the "fringes of this second camp." This is because he thinks punishment is essentially retributive and cannot be justified, but that we must, if possible, avoid yielding to the preventive worldview. He argues that by borrowing from punishment its harsh methods we maintain the dignity of offenders when we subject them to these methods with the aim of leading them to abandon the defective motivational traits that resulted in the crimes. He calls his approach "correction" rather than "punishment," because it lacks the retributive element that makes punishment punishment. Correction, for Corrado, is the application of harsh treatment to those who have committed crimes, but it cannot avail itself of the support of retribution, and therefore requires support of another kind. To that end, Corrado explores the theory proposed by J.G. Fichte, a theory of criminal justice without moral presuppositions, and tests the conclusions of that exploration against the problem presented by psychopaths in our society.

In Chapter 9, John Callender examines three clinical cases so as to provide some real-life illustrations of severe offending and to promote discussion of the complex issues raised by the cases. These questions are: How well do legal definitions of insanity map on to the reality of mental illness? What would be a just outcome in these three cases? What does it mean to treat someone as a person rather than an object? Is it possible that treating people as responsible agents promotes injustice by ignoring the very real constraints faced by many people in conforming their behavior to the law? And does retributive punishment convert complex human tragedies into simple dichotomies of good and evil, guilty or innocent, sane or insane, and right or wrong? Through examining his three case studies, Callender 
argues that, while our retributive impulse may have served the purpose of regulating social behavior in our evolutionary past, it is one of a range of instinctive impulses that has outlived its usefulness. It is less easy to justify anger and revenge when we know that someone is laboring under severe disabilities in relation to the ability to do what is right. The first case, for example, provides an illustration of how many offenders are themselves victims of traumatization. The second case highlights how the concept of legal insanity is a construct that sometimes maps poorly on the reality of mental illness and the ways in which this can alter personality and behavior. In cases such as these, retributive punishment inflicts new harm on already damaged people. Finally, in the third case, we see how a therapeutic response aimed at reduction of future harm to the offender and to other people produced the most humane and effective outcome.

In Chapter ro, Elizabeth Shaw examines the implications of free will skepticism for the process of establishing criminal liability in a trial. Currently, it is a general principle of UK and US law that before a person can be convicted of a crime the prosecution must prove three things. First, the accused must have performed the actus reus - the prohibited act. Second, the prosecution must prove mens rea - a mental state such as intention or recklessness. Third, the accused must lack a valid defense, such as self-defense. Shaw argues that these prerequisites for criminal liability should be retained and she offers a rationale for them that does not depend on the concepts of free will and retribution - one that appeals to considerations such as the value of liberty and moral communication. She concludes that, even if the notions of free will and retributive responsibility were abandoned, the mens rea and actus reus requirements and various defenses could still be retained. However, some of these legal rules, as well as the rationale behind them, would need to be revised.

The collection concludes with Farah Focquaert's chapter (Chapter I I) on free will skepticism and criminal punishment. If, as she contends, it is extremely unlikely that we possess the kind of free will that legitimates desert-based punishment, then the rationally defensible route is to adopt a cautionary perspective that draws on non-desert-based criminal justice procedures that are fair and just to all parties involved. She proceeds to analyze the options available, which include the following: (I) we can acknowledge that we do not have a justification for desert-based moral responsibility but choose to disregard this knowledge at both trial (determining guilt versus nonguilt) and sentencing (punishment) phases; (2) we can acknowledge this and disregard it at trial but not sentencing phase; (3) we can acknowledge this and take it into account during both the trial and 
sentencing phase. Taking these options into account, she presents a nonexhaustive list of potential models to effectively address criminal behavior and critically assesses the most striking difficulties each of these models faces. She concludes that innovative criminal justice systems need, at the very least, to continue to identify causal responsibility, promote taking responsibility for one's future behavior, and thoroughly respond to victims' rights and needs. The attribution of moral guilt and the implementation of desert-based punishment face numerous objections. We need to start a debate on the desirability of a criminal justice model that focuses on causal responsibility and taking responsibility; a model, she contends, that aims to achieve victim recovery, restitution, and restoration by implementing forward-looking justice mechanisms.

\section{REFERENCES}

Ashworth, A. (1994). Justifying the grounds of mitigation. Criminal Justice Ethics, I2( 5$), 8$.

Balaguer, M. (2009). Free Will as an Open Scientific Problem. Boston: MIT Press.

Bargh, J. A. (1997). The automaticity of everyday life. In R. S. Wyer, Jr., ed., The Automaticity of Everyday Life: Advances in Social Cognition, Vol. Io. Mahwah, NJ: Erlbaum, pp. I-6I.

(2008). Free will is un-natural. In J. Baer, J. C. Kaufman, and R. F. Baumeister, eds., Are We Free? Psychology and Free Will. New York: Oxford University Press, pp. I $28-154$.

Bargh, J. A., and T. L. Chartrand. (1999). The unbearable automaticity of being. American Psychologist, 54(7), 462-479.

Bargh, J. A., and M. J. Ferguson. (2000). Beyond behaviorism: On the automaticity of higher mental processes. Psychological Bulletin, I26(6), 925-945.

Baumeister, R. F. (2008). Free will in scientific psychology. Perspectives of Psychological Science, 3(I), I4-I 9 .

Baumeister, R. F., E. J. Masicampo, and C. N. DeWall. (2009). Prosocial benefits of feeling free: Disbelief in free will increases aggression and reduces helpfulness. Personality and Social Psychology Bulletin, 35(2), 260-268.

Bloom, P. (2004). Descartes' Baby. New York: Basic Books.

Boonin, D. (2008). The Problem of Punishment. New York: Cambridge University Press.

Caruso, G. D. (2012). Free Will and Consciousness: A Determinist Account of the Illusion of Free Will. Lanham, MD: Lexington Books.

Caruso, G. D. (2013). Introduction: Exploring the illusion of free will and moral responsibility. In G. D. Caruso, ed., Exploring the Illusion of Free Will and Moral Responsibility. Lanham, MD: Lexington Books, pp. I-I6.

(2015). If consciousness is necessary for free will, then people are less responsible than we think. Journal of Consciousness Studies, 22(7-8), 49-60. 
(2016). Free will skepticism and criminal behavior: A public health-quarantine model. Southwest Philosophy Review, 32(I), $25-48$.

(2017). Free will skepticism and the questions of creativity: Creativity, desert, and self-creation. Ergo 3(23), 591-607.

Caruso, G. D. (2018a). Skepticism about moral responsibility. Stanford Encyclopedia of Philosophy: https://plato.stanford.edu/entries/skepticism-moralresponsibility/.

(2018b). Origination, moral responsibility, and life-hopes: Ted Honderich of determinism and freedom. In G. D. Caruso, ed., Ted Honderich on Consciousness, Determinism, and Humanity. London: Palgrave Macmillan, pp. I95-2I6.

(20I 8c). Justice without retribution: An epistemic argument against retributive criminal punishment. Neuroethics, DOI: I0. I oo7/s I 2 I 52-0 I 8-9357-8.

(2018d). Consciousness, free will, and moral responsibility. In R. J. Gennaro, ed., The Routledge Handbook of Consciousness. London: Routledge, pp. 78-9I.

(20 I 9a). A defense of the luck pincer: Why luck (still) undermines free will and moral responsibility. Journal of Information Ethics, April/May issue.

(2019b). Free will skepticism and its implications: The case for optimism. In E. Shaw, D. Pereboom, and G. D. Caruso, eds., Free Will Skepticism in Law and Society: Challenging Retributivism, Ch.3 [this volume]. New York: Cambridge University Press.

Caruso, G. D., and S. Morris. (2017). Compatibilism and retributivist desert moral responsibility: On what is of central philosophical and practical importance. Erkenntnis, 82, 837-855.

Clark, T. (2013). Experience and autonomy: Why consciousness does and doesn't matter. In G. D. Caruso, ed., Exploring the Illusion of Free Will and Moral Responsibility. Lanham, MD: Lexington Books, pp. 239-254.

Corrado, M. L. (20I7). Punishment and the burden of proof. UNC Legal Studies Research Paper. Available at SRRN: https://ssrn.com/abstract=2997654 or DOI: I0.21 39/ssrn.2997654.

Cotton, M. (2000). Back with a vengeance: the resilience of retribution as an articulated purpose of criminal punishment. American Criminal Law Review, 37(4), I3 I 3-I357.

Davies, P. S. (2009). Subjects of the World: Darwin's Rhetoric and the Study of Agency in Nature. Chicago: University of Chicago Press.

Dingwall, G. (2008). Deserting desert? Locating the present role of retributivism in the sentencing of adult offenders. The Howard Journal of Crime and Justice, 47(4), 400-4IO.

Doris, J. M. (2002). Lack of Character: Personality and Moral Behavior. Cambridge, MA: Cambridge University Press.

Double, R. (I991). The Non-Reality of Free Will. Oxford: Oxford University Press.

Focquaert, F. (2019). Free will skepticism and criminal punishment: A preliminary ethical analysis. In E. Shaw, D. Pereboom, and G. D. Caruso, 
eds., Free will Skepticism in Law and Society: Challenging Retributivism, Ch.I I [this volume]. New York: Cambridge University Press.

Focquaert, F., A. L. Glenn, and A. Raine. (201 8). Free will skepticism, freedom, and criminal behavior. In G. D. Caruso and O. Flanagan, eds., Neuroexistentialism: Meaning, Morals, and Purpose in the Age of Neuroscience. New York: Oxford University Press, pp. 235-250.

Gordon, G. (1984). The Criminal Law of Scotland, Volume I. Edinburgh: W. Green.

Haidt, J. (200I). The emotional dog and its rational tail: A social intuitionist approach to moral judgment. Psychological Review, Io8, 8 I4-834.

Hodgson, D. (2009). Criminal responsibility, free will, and neuroscience. In N. Murphy, et al., eds., Downward Causation and the Neurobiology of Free Will. Berlin: Springer-Verlag, pp. 227-242.

Honderich, T. (1988). A Theory of Determinism: The Mind, Neuroscience, and Life-Hopes. Oxford: Oxford University Press.

Honderich, T. (2002). How Free Are You?: The Determinism Problem, 2nd edn. Oxford: Oxford University Press.

Horder, J. (1996). Determinism, liberalism and criminal law. Current Legal Problems, 49: I 59 .

(2004). Excusing Crime. New York: Oxford University Press.

Kaye, A. (2005). Resurrecting the causal theory of excuses. Nebraska Law Review, 83, I I I 6.

King, M., and P. Carruthers. (2012). Moral responsibility and consciousness. Journal of Moral Philosophy, 9, 200-228.

Levy, N. (2005). Libet's impossible demand. Journal of Consciousness Studies, $\mathbf{I 2}$ (I 2), 67-76.

Levy, N. (20 I I). Hard Luck: How Luck Undermines Free Will and Moral Responsibility. Oxford: Oxford University Press.

Levy, N. (2012). Skepticism and sanctions: The benefits of rejecting moral responsibility. Law and Philosophy, 3 I, 477-493.

20I 4. Consciousness and Moral Responsibility. New York: Oxford University Press.

Lewis, P. J. (2016). Quantum Ontology: A Guide to the Metaphysics of Quantum Mechanics. Oxford: Oxford University Press.

Libet, B. (1985). Unconscious cerebral initiative and the role of conscious will in voluntary action. Behavioral and Brain Science, 8, 529-566.

(1999). Do we have free will? Journal of Consciousness Studies, 6(8-9), 47-57. Reprinted in Robert Kane, ed., The Oxford Handbook of Free Will. New York: Oxford University Press, 2002, pp. 55 I-564.

Libet, B., C. A. Gleason, E. W. Wright, and D. K. Pearl. (1983). Time of conscious intention to act in relation to onset of cerebral activity (readiness-potential): The unconscious initiation of a freely voluntary act. Brain, 106, 623-642.

Litton, P. (2005). The "abuse excuse" in capital sentencing trials: Is it relevant to responsibility, punishment, or neither? American Criminal Law Review, 42, I027-1072. 
Mele, A. (2009). Effective Intentions. New York: Oxford University Press.

Moore, M. (1985). Causation and excuses. California Law Review, 73(4), Io9 I.

Moore, M. (1997). Placing Blame. New York: Oxford University Press.

Morris, N. (1982). Madness and the Criminal Law. Chicago: University of Chicago Press.

Morris, S. (201 5). Science and the End of Ethics. New York: Palgrave Macmillan.

Nadelhoffer, T. (20II). The threat of shrinking agency and free will disillusionism. In L. Nadel and W. Sinnott-Armstrong, eds., Conscious Will and Responsibility: A Tribute to Benjamin Libet. New York: Oxford University Press, pp. I73-I88.

(20I4). Dualism, libertarianism, and scientific skepticism about free will. In W. Sinnott- Armstrong, ed., Moral Psychology: Neuroscience, Free Will, and Responsibility, Vol. 4. Cambridge, MA: MIT Press, pp. 209-2 I6.

Nahmias, E. (2002). When consciousness matters: A critical review of Daniel Wegner's The Illusion of Conscious Will. Philosophical Psychology, I5(4), 527-54I.

(20 I I). Intuitions about free will, determinism, and bypassing. In R. Kane, ed., The Oxford Handbook of Free Will, 2nd edn.. New York: Oxford University Press, pp. 555-576.

Nietzsche, F. (I 886/I992). Beyond Good and Evil. Trans. Walter Kaufmann. New York: Random House.

Nisbett, R. E., and T. D. Wilson. (I977). Telling more than we can know: Verbal reports on mental processes. Psychological Review, 84, 23 I-259.

Pereboom, D. (2001). Living Without Free Will. New York: Cambridge University Press.

Pereboom, D. (2013a). Optimistic skepticism about free will. In P. Russell and O. Deery, ed., The Philosophy of Free Will: Selected Contemporary Readings. New York: Oxford University Press, pp. 42 I-449.

(2013b). Skepticism about free will. In G. D. Caruso, ed., Exploring the Illusion of Free Will and Moral Responsibility. Lanham, MD: Lexington Books, pp. 19-40.

(20I4.) Free Will, Agency, and Meaning in Life. Oxford: Oxford University Press.

Pereboom, D., and G. D. Caruso. (2018). Hard-incompatibilist existentialism: Neuroscience, punishment, and meaning in life. In G. D. Caruso and O. Flanagan, Neuroexistentialism: Meaning, Morals, and Purpose in the Age of neuroscience. New York: Oxford University Press, pp. 193-222.

Pillsbury, S. H. (I992). The meaning of deserved punishment: an essay on choice, character, and responsibility. Indiana Law Journal, 67(3), 719-752.

Robinson, P. H. (2008). Distributive Principles of Criminal Law: Who Should Be Punished How Much. New York: Oxford University Press.

Shaw, E. 20 I I. Free will, punishment and neurotechnologies. In B. van den Berg and L. Klaming, eds., Technologies on the Stand: Legal and Ethical Questions in Neuroscience and Robotics. Nymegen: Wolf Legal Publishers, pp. I 277-I 294 . 
Shaw, E. (2014). Free Will, Punishment and Criminal Responsibility. Dissertation. University of Edinburgh. Available at: www.era.lib.ed.ac.uk/handle/I $842 /$ 9590.

Shaw, E. (2019). The implications of free will skepticism for establishing criminal liability. In E. Shaw, D. Pereboom, and G. D. Caruso, eds., Free Will Skepticism in Law and Society: Challenging Retributivism, Ch.Io [this volume]. New York: Cambridge University Press.

Sie, M. (20I3). Free will, an illusion? An answer from a pragmatic sentimentalist point of view. In G. D. Caruso, ed., Exploring the Illusion of Free Will and Moral Responsibility. Lanham, MD: Lexington Books, pp. 273-290.

Sie, M., and A. Wouters. (2010). The BCN challenge to compatibilist free will and personal responsibility. Neuroethics, 3(2), I2 I-I 33 .

Smilansky, S. (2000). Free Will and Illusion. New York: Oxford University Press.

Soon, C. S., M. Brass, H-J. Heinze, and J-D. Haynes. (2008). Unconscious determinants of free decisions in the human brain. Nature Neuroscience, I I (5), 543-545.

Strawson, G. (1986). Freedom and Belief. Oxford: Oxford University Press.

(1994). The impossibility of moral responsibility. Philosophical Studies, 75(I), $5-24$.

(20 I I). The impossibility of ultimate responsibility? In R. Swinburne, ed., Free Will and Modern Science. London: British Academy, pp. I26-I 40.

Strawson, P. F. (1962). Freedom and resentment. Proceedings of the British Academy, 48,I-25. Reprinted in D. Pereboom, ed., Free Will, pp. I I9-I 42. Hackett.

Tadros, V. (2005). Criminal Responsibility. New York: Oxford University Press.

Tonry, M. (2004). U.S. sentencing systems fragmenting. In M. Tonry, ed., Panel Reform in Overcrowded Times. New York: Oxford University Press, pp. $2 \mathrm{I}-28$.

Vohs, K. D., and J. W. Schooler. (2008). The value of believing in free will: Encouraging a belief in determinism increases cheating. Psychological Science, I9, 49-54.

Vuoso, G. (I987). Background, responsibility, and excuse. Yale Law Journal, 96(7), I66I-I686.

Waller, B. (20 I I). Against Moral Responsibility. Cambridge, MA: MIT Press.

Waller, B. (2013). The stubborn illusion of moral responsibility. In G. D. Caruso, ed., Exploring the Illusion of Free Will and Moral Responsibility. Lanham, MD: Lexington Books, pp. 65-86.

(20I4a). The culture of moral responsibility. Southwest Philosophical View, 30(I), 3-I 7 .

Waller, B. (20 I 4b). The Stubborn System of Moral Responsibility. Cambridge, MA: MIT Press.

(2015). Restorative Free Will: Back to the Biological Base. Lanham, MA: Lexington Books.

Wegner, D. M. (2002). The Illusion of Conscious Will. Cambridge, MA: Bradford Books, MIT Press. 
Wegner, D. M., and T. Wheatley. (I999). Apparent mental causation: Sources of the experience of will. American Psychologist, 54, 480-49I.

Western, P. (2006). An attitudinal theory of excuse. Law and Philosophy, 25, 289.

Wilson, T. (2002). Strangers to Ourselves: Discovering the Adaptive Unconscious. Cambridge, MA: The Belknap Press of Harvard University Press.

Zimmerman, M. (20I I). The Immorality of Punishment. New York: Broadview Books. 
Downloaded from https://www.cambridge.org/core. University of Texas Libraries, on 16 Sep 2019 at 14:31:51, subject to the Cambridge Core terms of use, available at https://www.cambridge.org/core/terms. https://doi.org/10.1017/9781108655583.001 